\title{
Herbert Hoover and
}

the Issue of Race

George F. Garcia

HERBERT HOOVER WAS CONSIDERED A RACIST BY MANY OF HIS black contemporaries. W. E. B. Dubois, the great civil rights leader, charged Hoover with being an undemocratic racist who saw blacks as a species of "sub-men." Walter White, the Executive Director of the National Association for the Advancement of Colored People (NAACP) during Hoover's presidency, contemptuously referred to Hoover as "the man in the lily-White House." 2 Even Robert R. Moton, the conservative successor to Booker T. Washington as political advisor to Republican presidents on the "race question," came to believe that by his actions as president, Hoover had shown his contempt for blacks. $^{3}$

Dissatisfaction with Hoover among blacks was widespread during his administration. John Hope Franklin, the dean of black historians, argues convincingly that Hoover was largely responsible for laying the foundation for disaffection of blacks from the Republican party during his presidency. ${ }^{4}$

Much of the black criticism of Hoover was due to his southern policy as president. The first Republican since reconstruction to break the solid South in 1928, Hoover moved to consolidate his southern victory by openly purging blacks from the leadership positions in the southern wing of the G.O.P. with the

'The Crisis, XXXV (May, 1928), 168.

${ }^{2}$ Walter White, A Man Called White (New York: The Viking Press, 1948), 102.

${ }^{3}$ Letter, Moton to Newton, April 18, 1930, Parker file, Presidential Papers, Herbert Hoover Papers (HHP), Herbert Hoover Presidential Library (HHPL).

“John Hope Franklin, From Slavery to Freedom (New York: Vintage Books, 1969), 524. 
expressed purpose of attracting southern whites to join the party of Lincoln. The policy failed miserably as conditions in the South were not really propitious for Republicanizing the region, and the poorly conceived and badly implemented efforts to do so worked in conjunction with the Depression to move large numbers of blacks into a relatively permanent affiliation with the Democrats. ${ }^{5}$

If the record is clear regarding what blacks thought of Hoover, it is less clear what Hoover himself thought about the issue of race. Like many of his generation, Hoover combined an implicit acceptance of white supremacy with a deep devotion to liberal Democracy. And to understand how he reconciled these in his own mind, it is necessary to look at his background and at the ideas and values that helped to shape his thinking.

Born in an Iowa village in 1874 to a Quaker family of modest means, orphaned at the age of ten, and reared by an uncle in Oregon, Hoover had been exposed from the beginning to the Quaker ideal of humanitarian service, both as it applied to community living and as it had manifested itself in such phenomena as abolitionism and missionary work among the Indians. ${ }^{6}$ To this ideal he owed much of the drive that made him a philanthropist, uplifter, and moral philosopher. Yet joined with this formative force and also deeply influential in determining the ideas and values that he would espouse were two other major experiences.

One was his education at Stanford University and his subsequent involvement in the work of engineering societies and scientific groups. From such quarters he acquired a deep faith in scientific methods and evolutionary processes. He learned to think in naturalistic and organic terms, and while rejecting Social Darwinism's stress on the survival of the fittest and the desirability of laissez-faire, decided that there were such things as natural laws, human instincts, and inherent racial traits that shaped given cultures. All of this made it easier for him to accept the pseudo science of the Social Darwinists that placed

${ }^{5}$ For a complete account of Hoover's southern strategy see George F. Garcia, "Herbert Hoover's Southern Strategy and the Black Reaction," (Unpublished M.A. Thesis, University of Iowa, 1972).

${ }^{6}$ Herbert Hoover, Memoirs, I: Years of Adventure, 1874-1920 (New York: The Macmillan Company, 1952), 4, 7-8, 12. 
the black race at a lower rung on the evolutionary scale and argued that progress could come only through gradual uplifting. ${ }^{7}$

Hoover's engineering career was the other experience that shaped his values and ideas. It reinforced his faith in individual creativity, American traditions, and the inherent superiority of western culture. His own rise through the ranks from common mine laborer to the top of his profession-a multimillionaire by the time he was forty years of age-meant that he shared in the western exploitation of the "backward" areas of the world. First as an employee and partner in the British mining firm of Bewick, Moreing, later as a free lance engineer whose consultation and organizational work took him to all parts of the world, Hoover became the epitome of a self-made man. ${ }^{8}$ Viewing society from this vantage point, he was inclined to stress the drive and creativity inherent in individual initiative, the soundness and justice of a system in which such social mobility was possible, and the racial "differences" that enabled representatives of the white race to organize, control, and improve the world.

In his Principles of Mining, for example, published in 1909, Hoover discussed mining productivity not only as a function of the individual miner's "skill, intelligence, and application" but also as a factor dependent upon the racial characteristics of the labor force. White workers, he argued, were of a higher "mental order" and possessed higher "intelligence" than "Asiatics and Negroes [sic]." They were, he argued, better "coordinated" and more likely "to take initiative," and for this reason, it was cheaper and more efficient to hire white rather than nonwhite workers. "Much observation," he continued, "leads the writer to the conclusion that, averaging actual results, one white man equals from two to three of the colored races, even in the simplest forms of mine work such as shoveling or tramming."'

Similarly, in recalling his experiences in China, Hoover observed that "no world-startling mechanical invention" had ever

'Ibid., 20-21. For a discussion of Social Darwinist thought, see Richard Hofstadter, Social Darwinism in American Thought, 1860-1915 (Philadelphia: University of Pennsylvania Press, 1945). See also Herbert Hoover, Principles of Mining (New York: McGraw-Hill Book Co., Inc., 1909), 162-163.

${ }^{8}$ Eugene Lyons, Herbert Hoover (Garden City, N.Y.: Doubleday \& Co., 1964), 56-74.

${ }^{9}$ Hoover, Principles of Mining, 162-163. 
come out of Chinese culture, attributed this to a lack of mechanical "instincts" among the Chinese, and concluded that the greater penchant of the "European descended races" for mechanization and labor-saving devices was due to inherent differences in "racial instincts and qualities." 10 The Chinese, on the other hand, had a penchant for art, literature, and philosophy; and since their civil service system allowed an elite group of highly intelligent and courageous individuals to "rise from the mass," they were able to make outstanding contributions in these fields. ${ }^{11}$ Again, as he saw it, progress had stemmed from allowing individual creativity to work within a relatively fixed biological potential, from arrangements, in other words, that provided for the "natural" rise of the "upper 10 percent" by "natural endowment." And the leadership of the United States in technology and industrial development, the areas of progress that really counted, stemmed both from the biological potential that it had inherited from superior races and nationalities ${ }^{12}$ and from its open system that gave "every boy and girl" a chance. ${ }^{13}$

Like others in the 1920 s, moreover, Hoover feared that this superior potential might be lost through racial mixing and "mongrelization." Writing to his close friend, Mark Requa of California, in 1924, he argued strongly in favor of Japanese exclusion, primarily on racial grounds. Since the "biological fact" made "mixture of bloods disadvantageous," he maintained, and since no population could "be included by immigration into another without contemplation of eventual mixture," it was essential that further immigration from Japan be stopped. ${ }^{14}$

Where Hoover departed from the conventional form of Social Darwinism was, first of all, in his belief that social progress could, within limits, be managed and speeded up through conscious and scientifically based changes in the social environment, and secondly, in his insistence that the competitive struggle leading to the survival of the fittest must take place within an

\footnotetext{
${ }^{10}$ Hoover, Memoirs, I, 70. These recollections, although not published until 1952, were written much earlier.

"Ibid., 66-67.

${ }^{12}$ People of Hoover's generation used these two words interchangeably. See Stow Persons, American Minds (New York: Holt, Rinehart and Winston, 1958), 285.

${ }^{13}$ Herbert Hoover, Challenge to Liberty (New York: Charles Scribner's Sons, 1934), 19.

${ }^{14}$ Letter, Hoover to Mark Requa, April 21, 1924, Mark Requa File, Department of Commerce Papers, Herbert Hoover Papers (HHP), Herbert Hoover Presidential Library (HHPL).
} 
ethical and moral framework that would also lead to social justice, harmony, and cohesion. In a sense, he sought to combine a belief in natural determination and progress through individualistic competition with a faith in scientific management, social engineering, and moral uplift, all of which had been facets of his experience. And his effort to do so gives him a "progressive" side that could envision a part of the black man's backwardness as being due to environmental factors and could look to reform, education, and science as vehicles for improving his condition. Significantly, Hoover did lend his support to progressivism and the Progressive party, ${ }^{15}$ making it clear that he had no use for the selfish American individualism of the late nineteenth century, the type of naturalist thought that had supported it; and frequently, his optimism about the future and his faith in the scientific method and progressive education seemed to surpass the optimism and faith of those more commonly thought of as progressive philosophers.

Social improvement, however, as Hoover envisioned it, was to be the product of "progressive individualism," not of government coercion and regulation or of mass emotionalism and unthinking equalitarianism. The process, in other words, would be a voluntary one, guided and stimulated by a scientific and socialminded elite, implemented through community institutions and voluntary associations, and relying upon government only to maintain equality of opportunity, restrain "destructive impulses," provide needed data, and stimulate the formation and use of cooperative machinery. It was this type of reform that he equated with "true Progressivism." In his American Individualism, published in 1922, Hoover warned against both the autocratic, caste-ridden systems of Europe and the revolutionary socialist philosophy that was challenging them. ${ }^{16} \mathrm{He}$ tried to explain how voluntarism was producing a new and superior synthesis in America, why this new synthesis was imbued with great moral and spiritual purpose, and what was necessary to keep its evolution on the right path and prevent mass discontent and irrationality from destroying the individual's incentives and

${ }^{15}$ Hoover, Memoirs, I, 120.

${ }^{16}$ Arthur M. Schlesinger, Jr., The Crisis of the Old Order (Boston: Houghton Mifflin Company, 1957), 82-83. 
freedom that were an essential part of it. ${ }^{17}$ Clearly, when he recognized injustice in racial matters, ${ }^{18}$ he was likely to think in terms of educating and working through local leaders, not in terms of conflict and legal coercion.

More specifically, Hoover tended to agree with Booker T. Washington's view that the real path to black advancement lay through education and scientific research, the broadening of economic opportunity, and the patient development of an interracial leadership that would be willing to serve the cause, undertake appropriate associational and local activities, and help to change such attitudes as were based on prejudice rather than fact. This was the type of thing that he advocated as Secretary of Commerce in the 1920 s, partly because he was relying for advice upon Robert Russa Moton, Washington's successor at Tuskegee Institute. ${ }^{19}$ And at times, his willingness to act along such lines led him into daring and innovative schemes, particularly in trying to bring about the economic betterment of blacks.

In 1927, for example, as head of the relief operations following the Mississippi flood of that year, Hoover came into contact with the condition of black sharecroppers in the South, discussed the need for reform with Moton, and proposed a plan for long-term land and equipment loans that would enable the

${ }^{17}$ Herbert Hoover, American Individualism (Garden City, N.Y.: Doubleday, Doran and Co., 1922), 19, 22-24, 59-60. See also Walter Friar Dexter, Herbert Hoover and American Individualism (New York: The Macmillan Co., 1932), 115-169; Harris Gaylord Warren, Herbert Hoover and the Great Depression (New York: Oxford University Press, 1959), 34.

${ }^{18} \mathrm{At}$ times he seemed to be almost blind to such injustice and reluctant to admit that his cherished American System did not provide equality of opportunity for a large group of American citizens. In 1928, for example, he strongly resisted the idea of treating "the Negro as a separate entity." It was, he thought, "neither good psychology nor service to the colored folks." As president, he simply refused to believe some of the reports of unjust discrimination. When writing his memoirs, he emphasized not the acts of discrimination against black victims of the Mississippi flood, but his belief that they were "fed well, cared for medically, entertained by movies and concerts," and given one of the few "real holidays" they had ever known. And in the mid1950 s, speaking in Newberg, Oregon, he maintained that American blacks were better off living in the United States than anywhere else in the world. After all, he declared, they "owned more automobiles than . . . all three million Negroes in Africa." See Hoover to Emmet J. Scott, July 21, 1928, Campaign correspondence, 1928, Presidential Papers, HHP, HHPL; Kelly Miller, in Chicago Defender, October 12, 1929, 2; Interview with Mrs. Leon Thompson, November 16, 1966, Oral History Program, HHP, HHPL: Hoover, Memoirs Vol. II: The Cabinet and the Presidency, 1920-1933 (New York: The Macmillan Company, 1952), 126; and Hoover, Addresses Upon the American Road, 1955-1960 (Caldwell, Idaho: Caxton Printers, 1961), 84; Pete Daniel, Deep'n As It Come: the 1927 Mississippi River Flood, (New York: Oxford University Press, 1977), 141.

${ }^{19}$ William Hardin Hughes and Frederick D. Patterson, Robert Russa Moton of Hampton and Tuskegee (Chapel Hill: The University of North Carolina Press, 1956), 200. 
blacks to acquire small land holdings, help to break up the large plantations, and thus contribute to "a more stable social and economic situation." The plan, envisioning both a diversion of Red Cross funds and the creation of a land resettlement corporation backed by the federal land banks, was not implemented in 1927 and remained dormant during the Hoover administration. The Red Cross, Hoover decided, could not be used as a reform vehicle, and the Depression required him to focus attention on other matters. ${ }^{20}$ But during the New Deal, the Resettlement and Farm Security administrations, guided by Moton's close friend, Will Alexander, undertook various programs along just the lines that Hoover had suggested earlier. ${ }^{21}$

During the 1920s, Hoover also lent encouragement to such agencies as the black colleges, the National Urban League with its program of securing jobs and housing for urban migrants, the National Negro Business League as a developer of black businesses, and the Southern Interracial Commission with its hopes of promoting "adjustment" and "good-will." Yet such encouragement was usually balanced by a conviction that "local customs" could not be changed overnight. ${ }^{22}$ And while he did help to integrate employment in the U.S. Bureau of Census, ${ }^{23}$ he rarely challenged the Jim Crow system of de facto segregation openly and steered away from the notion that political change was a prerequisite for economic advancement. His principles, his experience, and his previous connections all led him to discount both the desirability of an alliance with the "New Negro" and the peril of shifting toward firmer support of a lily-white policy. And, not surprisingly, he continued to see no inconsistency between efforts to Republicanize the "best" elements in the South and efforts to serve the cause of black advancement.

${ }^{20}$ Letters, James L. Gieser to Hoover, August 27, 1927; Hoover to H. C. Couch, July 6, 1927, all in Mississippi Valley Flood file, Department of Commerce Papers, HHP, HHPL; Letters, Robert Moton to Hoover, January 12, 1933; Hoover to Moton, January 17, 1933, both in Robert Moton file, Presidential Papers, HHP, HHPL; Bruch Lohoff, "Herbert Hoover, Spokesman of Humane Efficiency: The Mississippi Flood of 1927," American Quarterly, XXI (Fall, 1970), 697; Daniel, op. cit., 138-140.

${ }^{21}$ Wilma Dykeman and James Stokely, Seeds of Southern Change, the Life of Will Alexander (Chicago: The University of Chicago Press, 1962), 218.

${ }^{22}$ Letter, Hoover to Walter White, June 21, 1927, Mississippi Valley Flood file, Department of Commerce Papers, HHP, HHPL.

${ }^{23}$ Memorandum, April 16, 1928, Colored People file, George Akerson Papers, HHP, HHPL. Still, in 1928, only 16 out of 3000 employees in the Bureau of the Census were blacks. 
In fact, as he saw it, the two might well compliment each other rather than being mutually contradictory.

Accordingly, as president, at the very time when Republican lily-white activities would reach their high-water mark, Hoover continued the type of "reform" in race relations that he had earlier espoused. In speeches honoring Tuskegee Institute and Howard University, for example, he reiterated his faith in education as a vehicle for promoting racial and inter-racial harmony, credited it with fostering the great "revolution in the social order" that blacks had already achieved, and called upon its purveyors to persist in developing a body of men whose "leadership and unselfishness" would bring further "advancement and adjustment." ${ }^{24}$ Through letters of encouragement, personal contributions, and the establishment in the U.S. Department of Labor of an advisor in charge of black economic development, he persisted in support of such groups as the Urban League and the National Negro Business League. ${ }^{25}$ Through public exhortations and private conferences, he sought to reduce conflict and mitigate abuses by bringing together "men and women of goodwill" and helping them to find areas in which they could "cooperate." ${ }_{26}$ Through special divisions of the Committee on Recent Social Trends, the White House Conference on Housing, and the National Advisory Committee on Education, he subjected various aspects of the "Negro Problem" to scientific inquiry. ${ }^{27}$ And through his long-time connections with the philanthropic Julius Rosenwald Fund, he arranged for the funding of and participated in the planning that led to a Conference on the Eco-

${ }^{24}$ Hoover, "The Contributions of Tuskegee to the Progress of the Negro Race," April 14, 1931, in William S. Myers, ed., State Papers and Other Public Writings of Herbert Hoover, I (Garden City, New York: Doubleday and Co., 1934), 545-547; and "Importance of Training Leaders of the Negro Race," June 10, 1932, in Ibid., II, 207.

${ }^{25}$ Letter, Hoover to Eugene K. Jones, April 1, 1929, State Papers, I, 26; Letters, Albon D. Holsey to Walter Newton, Julius Klein, and H. C. Dunn, all dated October 5, 1929; to Walter Newton, October 11, 1929; Eugene K. Jones to Lawrence Richey, July 25, 1932; Hoover to Jones, January 6, 1933, all in Colored Question file, Presidential Papers, HHP, HHPL.

${ }^{26}$ Letter, Hoover to Walter White, August 20, 1930, and Hoover, "Contributions of Tuskegee," both in State Papers, I. 371-372, 547; Letter, Hoover to Moton, December 3, 1929, Commission on Interracial Cooperation file, Presidential Papers, HHP, HHPL.

${ }^{27}$ Report of the President's Research Committee on Recent Social Trends, Recent Social Trends in the United States (New York: McGraw-Hill Book Company, Inc., 1933), 553-601; John Gries and James Ford, editors, Report of the Committee on Negro Housing (Washington, D.C.: National Capital Press, Inc., 1932); Ray Lyman Wilbur and Arthur Mastick Hyde, The Hoover Policies (New York: Charles Scribner's Sons, 1937, 84-86; The Crisis, XXXIX (January, 1932), 468. Interestingly, all of these studies recommended more federal intervention as a means of aiding the blacks. 
nomic Status of the Negro. ${ }^{28}$ As in numerous other areas, his intention was to use the government not as an instrument of reform but as an agency for promoting "constructive" private action.

In a sense, then, both his theory of white supremacy, buttressed as it was by a pseudo-scientific naturalism, and his theory of progress and reform conditioned Hoover to accept a lily-white strategy and continued racial segregation..$^{29}$ Respectable Republican leadership in the South, he seemed to feel, would draw that region into the mainstream of national progress. Then gradually, as education, economic development, and the spread of the cooperative spirit changed attitudes and local customs, blacks would also be granted the full benefits of the American system and be allowed to develop as far as their "inferior" biological heritage made possible. He could see nothing immoral, unnatural, or, as he defined the term, undemocratic in white superiority and a gradualist approach to black advancement.

${ }^{20}$ Report on the Conference on The Economic Status of the Negro, October 29, 1930, Colored Question file, Presidential Papers, HHP, HHPL.

${ }^{29}$ As president, Hoover not only cooperated with lily-white groups in the South, but also enforced strictly the federal measure segregating the armed forces and national parks. See Moton to Hoover, September 18, 1931; F. H. Payne to Hoover, October 6, 1931; Patrick Hurley to Walter White, October 2, 1931; R. W. Brooks to Hoover, August 8, 1932; U.S. Grant to Walter Newton, September 3, 1932; Newton to Brooks, September 3, 1932, all in Colored Question file, Presidential Papers, HHP, HHPL. 
Copyright of Annals of Iowa is the property of State of Iowa, by \& through the State Historical Society of Iowa and its content may not be copied or emailed to multiple sites or posted to a listserv without the copyright holder's express written permission. However, users may print, download, or email articles for individual use. 